\title{
A novel polymorphism in the IA promoter region of the vitamin $D$ receptor is associated with altered susceptibilty and prognosis in malignant melanoma
}

\author{
JA Halsall,', JE Osborne', L Potter', JH Pringle' and PE Hutchinson ${ }^{2}$ \\ 'Department of Cancer Studies and Molecular Medicine, University of Leicester, Leicester LE2 7LX, UK; ${ }^{2}$ Department of Dermatology, Leicester Royal \\ Infirmary, Leicester LEI 5WW, UK
}

\begin{abstract}
The association of Taq I and Fok I restriction fragment length polymorphisms of the vitamin D receptor with occurrence and outcome of malignant melanoma (MM), as predicted by tumour (Breslow) thickness, has been reported previously. We now report a novel adenine-guanine substitution - 1012 bp relative to the exon la transcription start site (A-I0I2G), found following screening by single-stranded conformational polymorphism of this promoter region. There was a total of $191 \mathrm{MM}$ cases, which were stratified according to conventional Breslow thickness groups, cases being randomly selected from each group to form a distribution corresponding to the known distribution of Breslow thickness in our area, and this population $(n=176)$ was compared to 80 controls. The A allele was over-represented in MM patients and, with GG as reference, odds ratio (OR) for $A G$ was 2.5 , 95\% confidence interval $(\mathrm{Cl})$ I.I - 5.7, $(P=0.03)$ and AA 3.3, $\mathrm{Cl}$ I.4-8. I, ( $=0.007)$. The outcome was known in I7I of 191 patients and the $A$ allele was related to the development of metastasis, the Kaplan-Meier estimates of the probability of metastasis at 5 years being: GG 0\%; AG 9\%, Cl 4- 16\%; AA 21\%, Cl 12-36\%; ( $P=0.008)$, and to thicker Breslow thickness groups $(P=0.04)$. The effect on metastasis was independent of tumour thickness and A-I0I2G may have predictive potential, additional to Breslow thickness. Neither the Fok I nor Taq I variants ( $\mathrm{f}$ and $\mathrm{t}$ ) were significantly related to the development of metastasis, although there was a strong relationship of $\mathrm{ftt}$ with the thickest Breslow thickness group $(P=0.005)$. There was an interaction between the $\mathrm{A}-\mathrm{IO}$ I $2 \mathrm{G}$ and Fok I polymorphisms $(P=0.025)$ and the Fok I variant enhanced the effect of the A allele of the $A-1012 \mathrm{G}$ polymorphism on metastasis, the probability of metastasis for AAff at 5 years follow-up being 57\%, Cl 24-92\%.

British Journal of Cancer (2004) 91, 765-770. doi:I0.1038/sj.bjc.6602006 www.bjcancer.com
\end{abstract}

Published online 6 July 2004

(C) 2004 Cancer Research UK

Keywords: VDR; promoter polymorphism; malignant melanoma

The polymorphisms of the vitamin $D$ receptor (VDR), reported in the literature, comprise a cluster of tightly linked polymorphisms at the $3^{\prime}$-end and two polymorphisms at the $5^{\prime}$-end of the gene. The $3^{\prime}$ polymorphisms are Apa 1 (Faraco et al, 1989) and Bsm 1 (Morrison et al, 1992) in intron 8, Taq 1(Morrison et al, 1992) in a silent site in exon 9 and a length polymorphism of a polyadenyl (polyA) microsatellite in the $3^{\prime}$-untranslated region (Ingles et al, 1997b), classified into long (L) and short (S) variants (L demonstrates linkage disequilibrium with $\mathrm{b}$, a, T). The $5^{\prime}$ polymorphisms are Fok 1(Saijo et al, 1991) situated in exon 2, 10 base pairs upstream from an ATG translation start point, and a recently described polymorphism in the promoter region, situated at $-3731 \mathrm{bp}$ relative to the exon 1a transcription start site (Arai et al, 2001) within a binding element of $\mathrm{Cdx}-2$, which is a caudalrelated homeodomain transcription factor. The $3^{\prime}$ region polymorphisms do not affect VDR protein structure, while Fok $1(\mathrm{C}-\mathrm{T}$ transition) alters an ACG codon resulting in a further upstream start codon and a three amino-acid extended protein (Saijo et al,

*Correspondence: Dr JA Halsall; E-mail: jah53@leicester.ac.uk Received 29 December 2003; revised 27 April 2004; accepted 17 May 2004; published online 6 July 2004
1991). Both the $3^{\prime}$ and Fok 1 polymorphisms have been reported to be functional in terms of VDR transactivation (Whitfield et al, 2000). Cdx-2 is important during the development of the intestine and in adults it has been shown to regulate VDR expression in the small intestine (Yamamoto et al, 1999). The expression of Cdx-2 has also been found in other tissues such as the brain and prostate. Polymorphism at the Cdx-2-binding site significantly alters the transcriptional activity of the $V D R$ promoter region (Arai et al, 2001).

Since 1996, there have been many reports of associations of polymorphisms of the VDR with systemic carcinomas. The $3^{\prime}$ polymorphisms have been reported to be associated with the occurrence and outcome, as assessed by metastasis or presence of adverse prognostic markers, of prostatic cancer (Taylor et al, 1996; Ingles et al, 1997c; Ingles et al, 1998; Ma et al, 1998; Habuchi et al, 2000; Hamasaki et al, 2001; Medeiros et al, 2002), breast cancer (Curran et al, 1999; Lundin et al, 1999; Ingles et al, 2000; Bretherton-Watt et al, 2001; Cui et al, 2001; Schondorf et al, 2003) and renal cancer (Ikuyama et al, 2002). Fok 1 polymorphisms have been reported to be associated with the outcome of prostate cancer (Hamasaki et al, 2002) and occurrence of breast (Ingles et al, 1997a) and colon (Wong et al, 2003) cancers. However, other studies have failed to find an association with prostate cancer 
(Jenkins et al, 1997; Dunning et al, 1999; Luscombe et al, 2001) or breast cancer (Correa-Cerro et al, 1999; Furuya et al, 1999; Watanabe et al, 1999; Blazer et al, 2000; Chokkalingam et al, 2001), but many of these (Jenkins et al, 1997; Correa-Cerro et al, 1999; Furuya et al, 1999; Watanabe et al, 1999; Blazer et al, 2000) were relatively limited studies of approximately 100 or less cases. The $\mathrm{Cdx}-2$ polymorphism has been linked with increased risk in cancer of the prostate (Bodiwala et al, 2004).

We have previously reported an association with the occurrence and, particularly, the outcome of malignant melanoma (MM), as assessed by Breslow tumour thickness and polymorphisms at the Fok 1 and Taq 1 restriction sites (ttff) (Hutchinson et al, 2000). We now describe a new polymorphism in the promoter region upstream of the exon la transcription start site, A-1012G. We report investigations into the relationship of the A-1012G and A$1012 \mathrm{G} / \mathrm{Taq} 1$ and A-1012G/Fok 1 genotype combinations with the occurrence and outcome of MM, in terms of the development of metastasis and as predicted by Breslow thickness and compare the strength of the A-1012G polymorphism with the corresponding relationships of Taq 1 and Fok 1 .

\section{MATERIALS AND METHODS}

\section{Single-stranded conformational polymorphism (SSCP) analysis}

All oligonucleotide primers used for PCR are shown in Table 1. A $\sim 2500 \mathrm{bp}$ region from $120 \mathrm{bp}$ upstream of exon $1 \mathrm{e}$ to $70 \mathrm{bp}$ downstream of exon 1d including exon la was amplified by PCR in 10 overlapping amplicons of $\sim 350 \mathrm{bp}$ (primers 1A/Dp1-10) for 35 cycles with an annealing temperature of $60^{\circ} \mathrm{C}$ in PCR buffer $(45 \mathrm{~mm}$ Tris- $\mathrm{HCl}$ (pH 8.8), $11 \mathrm{mM}\left(\mathrm{NH}_{4}\right)_{2} \mathrm{SO}_{4}, 4.5 \mathrm{mM} \mathrm{MgCl}_{2}, 110 \mu \mathrm{g} \mathrm{ml}^{-1}$ BSA, $6.7 \mathrm{~mm} \beta$-mercaptoethanol $4.4 \mu \mathrm{M}$ EDTA (pH 8.0), $200 \mu \mathrm{m}$ dNTPs). Each amplicon was screened for variation by SSCP in 36 control samples. A measure of $3 \mu \mathrm{l} \mathrm{PCR}$ product was added to $9 \mu \mathrm{l}$ denaturing loading buffer ( $95 \%$ formamide, $0.25 \%$ bromophenol blue, $0.25 \%$ xylene cyanol, $10 \mathrm{~mm}$ sodium hydroxide) and heated to $95^{\circ} \mathrm{C}$ for $3 \mathrm{~min}$, chilled on ice and loaded onto a $0.6-0.8 \times \mathrm{MDE}$ (BioWhittaker, 50620) gel, depending on amplicon size, in $0.6 \%$ TBE buffer and run at $500 \mathrm{~V}$ for $30 \mathrm{~min}$ followed by $270-350 \mathrm{~V}$ overnight, depending on amplicon size. Where variation was found, variant bands were reamplified from the gel and sequenced by Big Dye sequencing on an ABI prism 377 sequencer.

The possible effects of sequence variation on promoter activity were determined by the analysis of potential transcription factor- binding sites within variable regions using the TESS database (Schug and Overton, 1997).

\section{Genotype screening}

To screen for the promoter polymorphism in patients and controls, a $150 \mathrm{bp}$ region around the polymorphism was amplified using primer pair SNP1 (Table 1). PCR cycling was carried out with a $55^{\circ} \mathrm{C}$ annealing temperature for three cycles followed by $65^{\circ} \mathrm{C}$ for 37 cycles. The forward primer was adjacent to the polymorphism and mutated the sequence to introduce an EcoRV restriction site in the $A$ allele but not in the $G$ allele such that in subsequent EcoRV digestion $\left(37^{\circ} \mathrm{C}, 20 \mathrm{~h}\right)$, followed by agarose-gel electrophoresis, the $A$ allele was restricted and the $G$ allele remained uncut. Fok 1 and Taq 1 were amplified with the appropriate primers (Hutchinson et al, 2000) for 35 cycles with an annealing temperature of $60^{\circ} \mathrm{C}$. PCR products were then digested with Fok $1\left(37^{\circ} \mathrm{C}, 20 \mathrm{~h}\right)$ or Taq $1\left(65^{\circ} \mathrm{C}, 20 \mathrm{~h}\right)$. The Fok $1 \mathrm{~F}$ and Taq $1 \mathrm{~T}$ alleles were refractory to digestion, while the $\mathrm{f}$ and $\mathrm{t}$ alleles were restricted.

\section{MM studies}

Patients with a diagnosis of MM who attended the Pigmented Lesion Clinic between 1995 and 1997 were recruited. Patients with lentigo maligna melanoma were not included. It was attempted to recruit all patients, but this was not always possible in busy clinics. Documented data were age at presentation, gender, skin type based on the Fitzpatrick classification (Fitzpatrick, 1988), eye colour, hair colour at age 21 years, tumour site and Breslow group and presence of metastases on follow-up. Breslow thickness (defined as the vertical thickness of the tumour from the granular layer of the epidermis to the deepest part of the melanoma) was determined by specialist pathologists. On the basis of Breslow thickness, patients were divided into five conventional Breslow thickness groups ( 0 4); in situ, $<0.75 \mathrm{~mm}, 0.75-1.49 \mathrm{~mm}, 1.5-3.49 \mathrm{~mm}$ and $\geqslant 3.5 \mathrm{~mm}$ (Mackie et al, 1985). For the occurrence studies, a subsample of patients were stratified according to Breslow thickness group to conform with frequencies within groups according to the reported distribution in the Leicestershire area $(n=738)$ (Osborne and Hutchinson, 2001). Controls consisted of UK Caucasian patients not known to have cancer. This study was approved by the local Ethics Committee and written informed consent was given by the patients.

Table I Oligonucleotide sequences used as PCR primers

\begin{tabular}{|c|c|c|c|}
\hline Primer pair & Forward primer & Reverse primer & Amplicon position (bp) \\
\hline |A/Dp | & CTGATGACGGCATGTGCT & CAGCCTTTGTGGAGGAGAG & -2119 to -1755 \\
\hline IA/Dp2 & CAGTGGGATGTGCAGAGAGA & GCTAGCGGTGATTCTTGTGG & -1979 to -1529 \\
\hline IA/Dp4 & ATGGTCCATTCCCAAGTTCA & CAGAGGGACAAGGTGAAAGG & $-|4| \mid$ to $-|05|$ \\
\hline IA/Dp5 & AGCAGATTTGCTGGGCTCTA & TGCTTCCCTTGACTGTGTGA & -1163 to -818 \\
\hline IA/Dp6 & TCCCACTGCACAGTGAGTTC & AAGTGGAAACCGGAGTTGC & -914 to -554 \\
\hline IA/Dp7 & GATATCGGGTGGGAGCAAT & TGGGACAGAGTTGTCGATGA & -594 to -232 \\
\hline |A/Dp 10 & TCTCAGCGGTAAACTTGGCTA & AGACCCAACTCCACCATCAC & +186 to +535 \\
\hline SNPI & ССTССTCTGTAAGAGGCGAATAGCGAT & GGACAGGTGAAAAAGATGGGGTTC & -1039 to $-86 \mid$ \\
\hline Fok I & CTGGCACTGACTCTGGCTCT & TGCTTCTTCTCССTCССTTT & -48 to $+199^{a}$ \\
\hline Taq I & CAGAGCATGGACAGGGAGCAAG & CGGCAGCGGATGTACGTCTGCAG & -260 to $+338^{\mathrm{b}}$ \\
\hline
\end{tabular}

$\mathrm{PCR}=$ polymerase chain reaction; $\mathrm{bp}=$ base pair. All amplicon positions are relative to the exon la start site except ${ }^{\mathrm{a}}$ relative to the start of exon 2 and ${ }^{\mathrm{b}}$ relative to the start of exon 9 . 


\section{Statistics}

Occurrence and Breslow thickness data were analysed by contingency tables (Unistat Statistical Package, version 5.0, Unistat, UK) and logistic regression (Stata software package, version 7.0, Stata Corporation, Texas, USA). Metastatic data were analysed using the Kaplan-Meier product limit estimator (Unistat), with the log-rank comparison statistic, and by the Cox's proportional-hazard model (Stata). Interactions were assessed by the Cox's likelihood-ratio test (Stata).

\section{RESULTS}

\section{Promoter screening}

Single-stranded conformational polymorphism revealed variation in the $1 \mathrm{~A} / \mathrm{Dp} 5$ region $(-1163$ to $-818 \mathrm{bp})$. Sequencing of the variant bands revealed an A-G polymorphism, at $-1012 \mathrm{bp}$ relative to the exon 1a transcription start site (Figure 1). Therefore, the sequence in the region was either: -1020 ATAGCAATATCTTC or -1020 ATAGCAATGTCTTC.

Analysis with the TESS database revealed a strong GATA-3 corebinding site at this locus in the A allele (given in italics above), which was not present on analysis of the $G$ allele.

\section{MM studies}

The percentages of $\mathrm{MM}$ in each Breslow thickness group presenting in Leicestershire in the past 10 years are as follows: in situ, $13.8 \%$; $<0.75 \mathrm{~mm}, 26.6 \%$; $0.75-1.49 \mathrm{~mm}, 21.5 \%$; $1.5-$ $3.49 \mathrm{~mm}, 21.0 \%$ and $\geqslant 3.5 \mathrm{~mm}, 17.1 \%$. A total of 191 patients were recruited. The numbers of patients randomly chosen for allocation to the respective thickness groups from the 191 patients were 24
(13.6\%), 49 (27.8\%), 35 (19.9\%), $38(21.6 \%)$ and $30(17.0 \%)$. The total number of MM patients for the occurrence study was therefore 176 (mean age 54.3 years, 110 females) and there were 80 controls (mean age 56.2 years, 40 females). Age or sex did not have a statistically significant relationship with $V D R$ promoter genotype in either controls or MM patients. In the metastatic outcome part of the study, there was a total of 171 of 191 patients in whom the outcome was known.

Table 2 shows allele and genotype frequencies in controls and MM patients. Genotype frequencies conformed to the HardyWeinberg equilibrium in both subject groups. The A allele was over-represented in the MM patients $(P=0.03)$. Similarly, AA genotype was more and GG less frequent in $M M$ patients $(P=0.03)$. Correcting for age and sex and with GG as reference, odds ratio (OR) for AG was $2.5,95 \%$ confidence interval (CI) 1.1 $5.7(P=0.03)$ and AA 3.3, CI 1.4-8.1, $(P=0.007)$.

The mean time to metastasis was 31 months (range 1-171 months $)(n=19)$ and mean follow-up time in patients not developing metastasis was 75 months $(3-255$ months $)(n=152)$. Figure 2 shows Kaplan-Meier curves for metastasis-free times for

Table 2 Allele and genotype frequencies of A-IOI2G in MM patients and controls

\begin{tabular}{lcclccc}
\hline & \multicolumn{2}{c}{ Alleles } & & \multicolumn{3}{c}{ Genotypes } \\
\cline { 2 - 3 } \cline { 5 - 7 } & A & G & & AA & AG & GG \\
\hline Controls & $86(54 \%)$ & $74(46 \%)$ & & $22(27 \%)$ & $42(52 \%)$ & $16(20 \%)$ \\
MM patients & $244(64 \%)$ & $140(36 \%)$ & & $66(38 \%)$ & $92(53 \%)$ & $16(9 \%)$ \\
& \multicolumn{2}{c}{$P=0.03$} & & $P=0.03$ & \\
\hline
\end{tabular}

$\mathrm{MM}=$ malignant melanoma
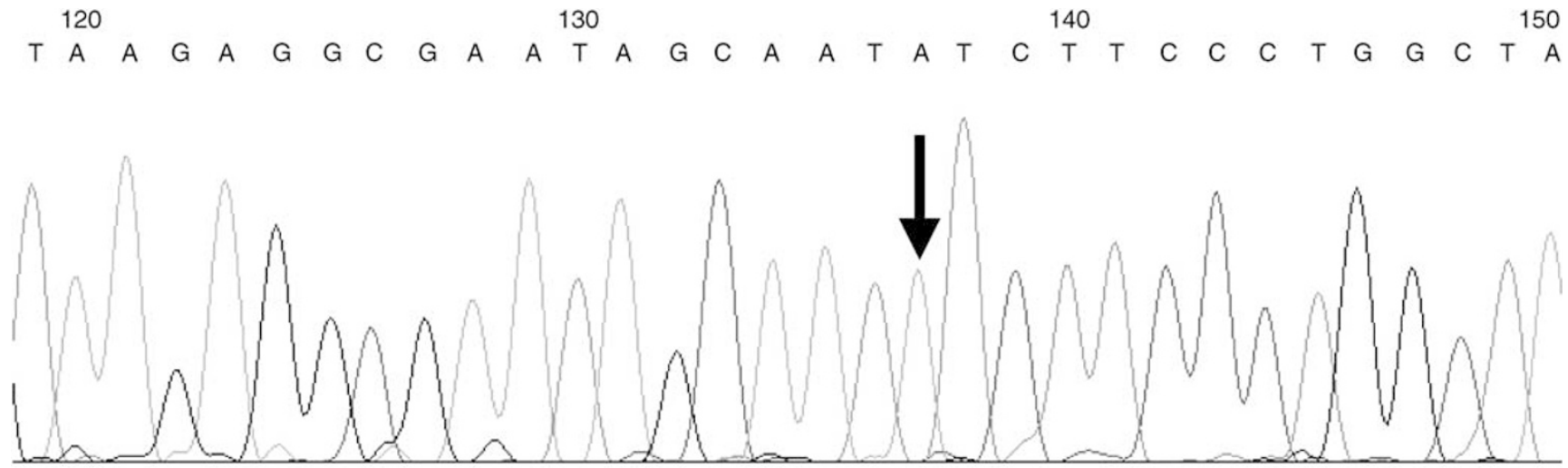

120 130
G $\quad C \quad A \quad A \quad A \quad T \quad G \quad T \quad C \quad$

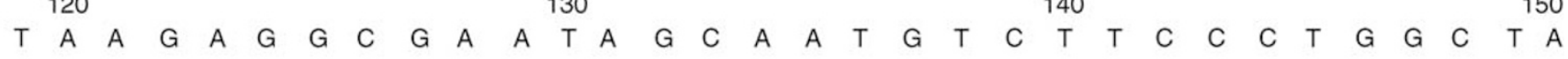

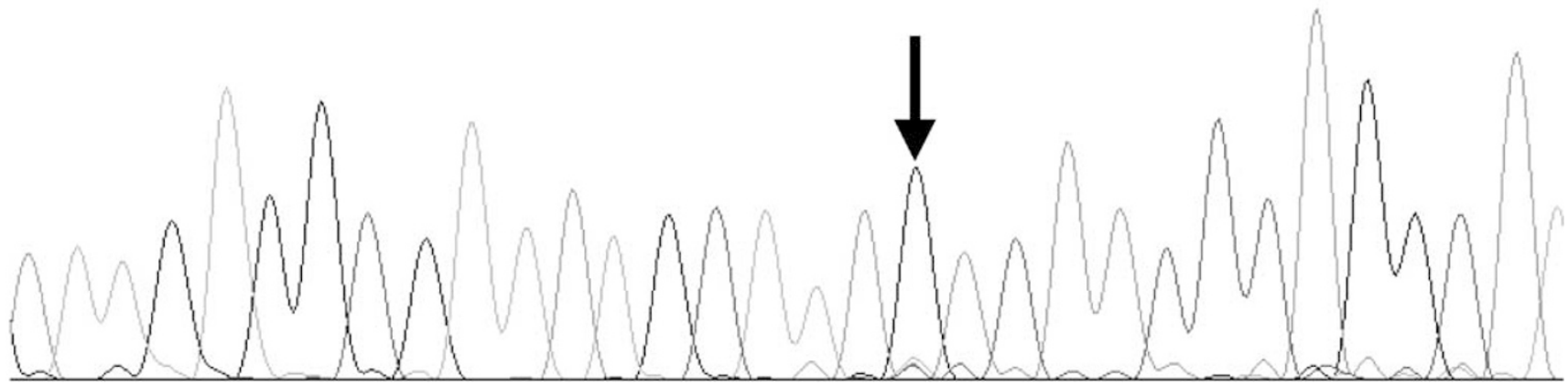

Figure I Sequencing traces of the region around the polymorphism, the variable base is marked by an arrow. 


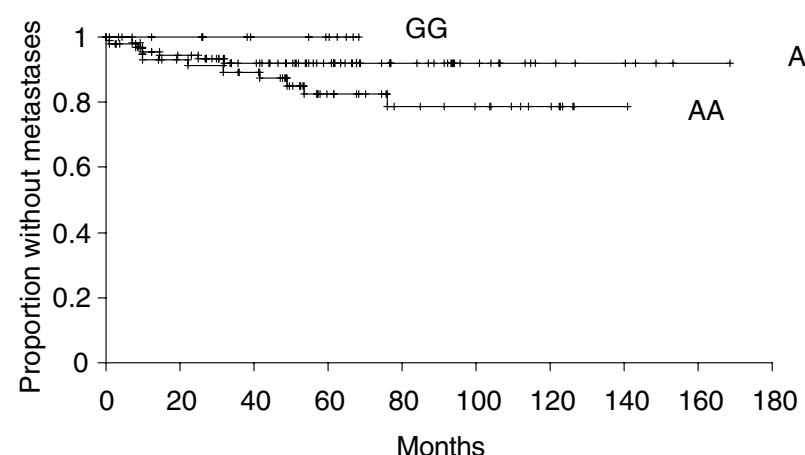

Figure 2 Kaplan-Meier estimates of the probability of metastasis for A-I0I2G genotypes.

Table 3 Results of Cox's proportional-hazard regression analysis (univariate) of metastatic rate on A-I0I2G, Fok I and Taq I genotypes, and on A-IOI2G genotype combinations with Fok I and Taq I

\begin{tabular}{llrlll}
\hline Polymorphisms & Genotype & Number & HR & $\mathbf{9 5 \%} \mathbf{C l}$ & Significance \\
\hline A-1012G & GG/AG & 110 & 1 & & \\
& AA & 59 & $\mathbf{2 . 9}$ & $1.1-7.5$ & $P=0.03$ \\
Fok & FF/Ff & 140 & 1 & & \\
& Ff & 30 & 1.3 & $0.4-4.1$ & $P=0.6$ \\
Taq & TT/Tt & 143 & 1 & & \\
& Tt & 26 & 1.5 & $0.5-4.6$ & $P=0.5$ \\
Fok/Taq & Other genotypes & 165 & 1 & & \\
& ff/tt & 4 & 2.2 & $0.3-16.3$ & $P=0.5$ \\
A-1012G/Taq & Other genotypes & 130 & 1 & & \\
& AATT & 27 & 2.5 & $0.9-7.4$ & $P=0.1$ \\
& Aatt & 11 & 3.1 & $0.8-11.2$ & $P=0.1$ \\
A-1012G/Fok & Other genotypes & 130 & 1 & & \\
& AAfF & 30 & $\mathbf{4 . 3}$ & $1.5-12.4$ & $P=0.006$ \\
& AAff & 9 & $\mathbf{8 . 6}$ & $2.5-29.6$ & $P=0.001$ \\
& AAfF/Ff & 50 & 1 & & \\
& AAff & 9 & $\mathbf{4 . 7}$ & $1.2-18.6$ & $P=0.03$ \\
\hline
\end{tabular}

$\mathrm{HR}=$ hazard ratio; $\mathrm{Cl}=95 \%$ confidence interval for hazard ratio estimate. Bold numerals represent statistically significant results.

the promoter genotypes, which differed significantly $(P=0.008)$. The Kaplan-Meier estimates of the probability of metastasis at 5 years follow-up were: GG 0\%; AG 9\%, CI 4-16\%; AA $21 \%$, CI $12-$ $36 \%$. The results of Cox's proportional-hazard regression analysis are shown in Table 3. As there were no metastases with genotype GG, hazard ratios (HR) for AA and AG compared with GG were not reliable and therefore AA vs AG/GG are shown, confirming a significantly worse prognosis for AA. Inclusion of the covariates, age at onset, male gender, skin type, eye and hair colour and lesional site made no significant impact on this (results not shown).

Conversely, the A-1012G polymorphism was not strongly associated with Breslow thickness $(n=191)$, although for Breslow thickness groups two, three and four combined $v s$ groups zero and one combined ( $\geqslant 1.5 \mathrm{~mm} v s<1.5 \mathrm{~mm}$ depth); OR for AA $v s$ other genotypes was 1.9 (CI 1.0-3.6, $P=0.04$ ). The relationship of promoter polymorphism and metastasis was reinvestigated correcting for Breslow thickness, when HR for AA vs any other genotype was 2.7 , which was very similar to the uncorrected value of 2.9, suggesting that the effect of the polymorphism on metastasis was largely independent of depth of invasion. Table 4 shows the
Table 4 Proportion of patients developing metastases in relation to Breslow group of the melanoma and A-IOI2G genotype

\begin{tabular}{llllll}
\hline \multicolumn{5}{c}{ Breslow thickness group } \\
\cline { 2 - 6 } & \multicolumn{1}{c}{ In situ } & $<\mathbf{0 . 7 5} \mathbf{~ m m}$ & $\mathbf{0 . 7 5}-\mathbf{I . 4 9} \mathbf{~ m m}$ & $\mathbf{I . 5}-\mathbf{3 . 4 9} \mathbf{~ m m}$ & $\geqslant \mathbf{3 . 5} \mathbf{~ m m}$ \\
\hline GG & $0 \%(0 / 3)$ & $0 \%(0 / 5)$ & $0 \%(0 / 3)$ & $0 \%(0 / 4)$ & $0 \%(0 / 2)$ \\
AG & $0 \%(0 / 13)$ & $0 \%(0 / 30)$ & $0 \%(0 / 17)$ & $17 \%(3 / 18)$ & $27 \%(4 / 15)$ \\
AA & $0 \%(0 / 7)$ & $8 \%(1 / 13)$ & $12 \%(2 / 16)$ & $14 \%(2 / 14)$ & $67 \%(6 / 9)$ \\
\hline () = number of patients developing metastasis/total number patients in each group.
\end{tabular}

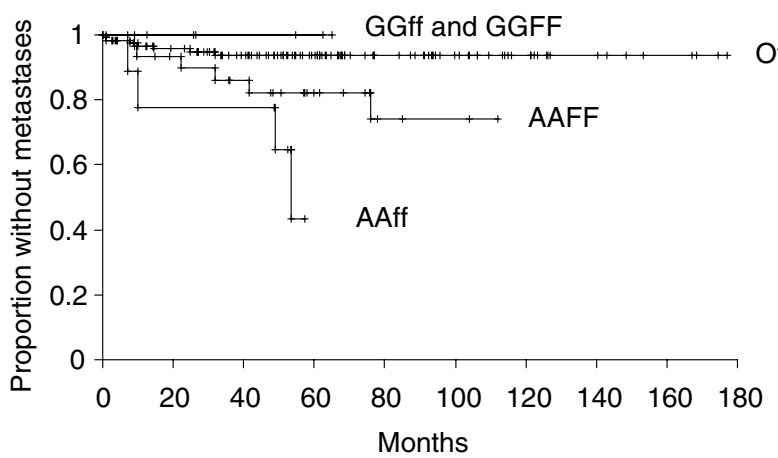

Figure 3 Kaplan-Meier estimates of the probability of metastasis for A-1012G/Fok I combination genotypes.

proportion of patients in each promoter genotype/Breslow thickness group who developed metastasis. The highest proportion occurred in patients who had both AA genotype and the thickest tumours (Breslow thickness $\geqslant 3.5 \mathrm{~mm}$, group 4). However, some patients with thin tumours developed metastasis but only in the presence of the AA genotype.

The Taq 1 homozygote variant (tt) was associated with Breslow thickness groups three and four combined (Breslow thickness $\geqslant 1.5 \mathrm{~mm}$ ) when corrected for age at presentation, sex, skin type eye and hair colour and site of MM (OR 3.1 CI 1.2-8.3, $P=0.02$ ) but the Fok 1 homozygote variant (ff) was not (OR 1.4, CI 0.6-3.5, $P=0.5$ ). The $\mathrm{fftt}$ genotype combination was strongly associated with the thickest Breslow thickness group, group 4 (OR 24, CI 3$225, P=0.005)$. Similarly, $t \mathrm{t}$, ff and ttff were not significantly associated with poorer prognosis in terms of metastasis (Table 3 ).

There was some correlation between A-1012G with Fok 1 polymorphisms (F and A), Spearman's rank correlation 0.15 $(P=0.01)$ but not with Taq $1(P=0.5)$. There was a statistically significant interaction of the A-1012G with Fok 1 polymorphisms $(P=0.025)$ but not with Taq 1 . Considering A-1012G/Fok 1 and A1012G/Taq 1 genotype combinations (Figure 3), the Kaplan-Meier estimates of the probability of metastasis at 5 years follow-up were AAff $57 \%$, CI $24-92 \%$; AAFF $18 \%$, CI $8-38 \%$; GGff $0 \%$; GGFF $0 \%$ and all other genotypes $6 \%$, CI $3-13 \%,(P=0.001)$. On Cox's proportional-hazard model regression (Table 3), there was a strong effect of AAff, which was associated with a greater metastatic rate than AAFF/Ff (HR 4.7, $P=0.03$ ) when corrected for the other covariates. This difference was greater than the corresponding comparison of ff $v s \mathrm{FF} / \mathrm{Ff}$ (HR 1.3, $P=0.6$ ).

\section{DISCUSSION}

This newly described polymorphism of the 1a promoter, A-1012G, has been found to be related to occurrence of MM (Table 2), the A allele being over-represented in the MM population. When investigating the effect of a variable on occurrence of a 
malignancy, it is necessary to employ a sample of patients which is representative in terms of severity of the disease in general if, as in this case, the variable is also related to the outcome. Failure to do this may be a cause of some of the conflicting results in the literature. The cases were therefore stratified according to Breslow thickness, which is the best single predictor of MM outcome.

The promoter polymorphism was clearly related to outcome as assessed by the development of metastasis (Figure 2, Table 3). There was a weaker relationship with thicker Breslow thickness groups. We have previously reported a relationship of Taq 1 and Fok 1 variant gene combination (ttff) with increased Breslow thickness (Hutchinson et al, 2000). This was true in the present study $(P<0.005)$, but the ttff genotype combination was not significantly associated with metastasis.

The relationship between the A-1012G genotype and development of metastasis was also analysed by Cox's proportional-hazard regression, correcting for Breslow group, when the promoter genotype retained significance. The $V D R$ would therefore appear to be related to both Breslow thickness and development of metastasis, but the effect on metastasis is at least partially independent of tumour thickness. This finding has potential importance in the interpretation of molecular mechanism of tumour spread. Also, the inclusion of the VDR promoter genotype when predicting MM outcome with Breslow thickness group should potentially enhance precision (Table 4). The highest proportion of metastases occurred in patients who had both AA genotype and the thickest tumours (Breslow thickness group 4). However, some thinner tumours developed metastasis, but usually in the context of AA genotype. Studies on a larger scale are required to further investigate the predictive capacity of this polymorphism.

Neither the Fok 1 nor Taq 1 polymorphism was significantly related to the development of metastasis. However, the promoter and Fok 1 combination genotype (AAff) was greatly associated with a higher propensity to metastasis (Table 3 ). The Fok 1 polymorphism appears to augment the effect of the promoter polymorphism, as evidenced by a significant statistical interaction on Cox's regression and a significant difference in prognosis associated with AAff compared with AAFf/AAFF genotype combinations (Table 3), despite no similar difference between ff and $\mathrm{Ff} / \mathrm{FF}$

The mechanism of action of this promoter polymorphism is not known. One possibility is that the polymorphism modulates docking of a transcription factor. The analysis of this region with the TESS database (Schug and Overton, 1997) demonstrates that the polymorphism is within the core sequence of a likely GATA-3binding site in the A allele, while this binding site is not present in the G allele. Merika and Orkin, (1993) demonstrated that DNA strands containing the core sequence AGATAT (the reverse orientation of the A allele) bound human GATA-3, while zero of
63 sequences shown to bind GATA-3 contained the core sequence AGACAT (the reverse orientation of the G allele). GATA-3 is an important transcription factor directing the polarisation of naïve $\mathrm{T}$ cells to Th-2 cells (Rengarajan et al, 2000). 1 1,25-dihydroxyvitamin $\mathrm{D}_{3}$ has been shown to upregulate GATA-3 gene expression and the GATA-3 protein promotes polarisation to Th-2 (Boonstra et al, 2001). The present findings would suggest that the GATA-3 response element in the A allele of the VDR promoter may produce a positive feedback loop and amplify the GATA-3-induced polarisation. Therefore, this polymorphism may influence immune response to cancer, particularly in cancers, such as MM, which show high expression of MAGE antigens. Such tumours are susceptible to Th-1 responses (Tatsumi et al, 2002). The argument would be that the A allele is associated with a Th-1 to Th-2 switch, which reduces the Th-1 cytotoxic response to cancer cells. A further possibility is that $\mathrm{A}-1012 \mathrm{G}$ is a determinant of whether transcription is initiated in exon $1 \mathrm{a}$ or $1 \mathrm{~d}$. Exon $1 \mathrm{~d}$ contains an alternative start codon, which can lead to the expression of a significantly $\mathrm{N}$-terminally extended protein (VDRB1). This is reported to have greater transactivation potential than the short protein, translated at the conventional start codon in exon 2 (VDRA) (Gardiner and Eisman, 2003), although this has not been consistently reported (Sunn et al, 2001). The majority of evidence is that vitamin $\mathrm{D}$ and the VDR have a protective effect in cancer (Osborne and Hutchinson, 2002). Therefore, if A-1012G were determining the transcription start site, then the $G$ allele would be expected to be associated with the VDRB1 protein and the A allele with the shorter VDRA protein, which would be further altered by the $\mathrm{f}$ allele of the Fok 1 polymorphism. This would be compatible with the finding of enhanced effect of AAff over AA found in the present study.

In conclusion, the novel $V D R$ promoter polymorphism, A-1012G, is related to MM occurrence and outcome as predicted by Breslow thickness but more particularly with the development of metastasis. This relationship is considerably stronger than the relationships of the Taq 1 and Fok 1 polymorphisms and their genotype combinations. The Fok 1 variant enhanced the effect of the A-1012G/Fok 1 polymorphism on metastasis. The effect on metastasis is at least partially independent of tumour thickness and A-1012G may have predictive potential in addition to Breslow thickness.

\section{ACKNOWLEDGEMENTS}

We are grateful to Dr Anthony A Fryer, Honorary Senior Lecturer, Human Genomic Research Group, Institute of Science and Technology in Medicine, Keele University Medical school, University Hospital of North Staffordshire, for his helpful suggestions and corrections to the text.

\section{REFERENCES}

Arai H, Miyamoto KI, Yoshida M, Yamamoto H, Taketani Y, Morita K, Kubota M, Yoshida S, Ikeda M, Watabe F, Kanemasa Y, Takeda E (2001) The polymorphism in the caudal-related homeodomain protein $\mathrm{Cdx}-2$ binding element in the human vitamin D receptor gene. J Bone Miner Res 16: $1256-1264$

Blazer III DG, Umbach DM, Bostick RM, Taylor JA (2000) Vitamin D receptor polymorphisms and prostate cancer. Mol Carcinogen 27: $18-23$

Bodiwala D, Luscombe CJ, French ME, Liu S, Saxby MF, Jones PW, Fryer AA, Strange RC (2004) Polymorphisms in the vitamin D receptor gene, ultraviolet radiation, and susceptibility to prostate cancer. Environ Mol Mutagen 43: $121-127$
Boonstra A, Barrat FJ, Crain C, Heath VL, Savelkoul HF, O'Garra A (2001) lalpha,25-Dihydroxyvitamin $\mathrm{d} 3$ has a direct effect on naive CD4(+) $\mathrm{T}$ cells to enhance the development of Th2 cells. J Immunol 167: 4974-4980

Bretherton-Watt D, Given-Wilson R, Mansi JL, Thomas V, Carter N, Colston KW (2001) Vitamin D receptor gene polymorphisms are associated with breast cancer risk in a UK Caucasian population. $\mathrm{Br} J$ Cancer 85: $171-175$

Chokkalingam AP, McGlynn KA, Gao YT, Pollak M, Deng J, Sesterhenn IA, Mostofi FK, Fraumeni Jr JF, Hsing AW (2001) Vitamin D receptor gene polymorphisms, insulin-like growth factors, and prostate cancer risk: a population-based case-control study in China. Cancer Res 61: $4333-4336$ 
Correa-Cerro L, Berthon P, Haussler J, Bochum S, Drelon E, Mangin P, Fournier G, Paiss T, Cussenot O, Vogel W (1999) Vitamin D receptor polymorphisms as markers in prostate cancer. Hum Genet 105: 281-287

Cui J, Shen K, Shen Z, Jiang F, Shen F (2001) Relationship of vitamin D receptor polymorphism with breast cancer. Zhonghua Yi Xue Yi Chuan Xue Za Zhi 18: 286-288

Curran JE, Vaughan T, Lea RA, Weinstein SR, Morrison NA, Griffiths LR (1999) Association of A vitamin D receptor polymorphism with sporadic breast cancer development. Int J Cancer 83: 723-726

Dunning AM, McBride S, Gregory J, Durocher F, Foster NA, Healey CS, Smith N, Pharoah PD, Luben RN, Easton DF, Ponder BA (1999) No association between androgen or vitamin $\mathrm{D}$ receptor gene polymorphisms and risk of breast cancer. Carcinogenesis 20: 2131-2135

Faraco JH, Morrison NA, Baker A, Shine J, Frossard PM (1989) ApaI dimorphism at the human vitamin D receptor gene locus. Nucleic Acids Res 17: 2150

Fitzpatrick TB (1988) The validity and practicality of sun reaction skin types I through VI. Arch Dermatol 124: 869-871

Furuya Y, Akakura K, Masai M, Ito H (1999) Vitamin D receptor gene polymorphism in Japanese patients with prostate cancer. Endocr J 46: $467-470$

Gardiner EM, Eisman JA (2003) Function of vitamin D receptor B1 and its extended $\mathrm{A} / \mathrm{B}$ region. In 12th Workshop on Vitamin $D$, Norman $\mathrm{AW}$, Bouillon R (eds) p 4, Maastricht: Riverside, University of California

Habuchi T, Suzuki T, Sasaki R, Wang L, Sato K, Satoh S, Akao T, Tsuchiya N, Shimoda N, Wada Y, Koizumi A, Chihara J, Ogawa O, Kato T (2000) Association of vitamin D receptor gene polymorphism with prostate cancer and benign prostatic hyperplasia in a Japanese population. Cancer Res 60: 305-308

Hamasaki T, Inatomi H, Katoh T, Ikuyama T, Matsumoto T (2001) Clinical and pathological significance of vitamin $\mathrm{D}$ receptor gene polymorphism for prostate cancer which is associated with a higher mortality in Japanese. Endocr J 48: $543-549$

Hamasaki $\mathrm{T}$, Inatomi $\mathrm{H}$, Katoh $\mathrm{T}$, Ikuyama $\mathrm{T}$, Matsumoto $\mathrm{T}$ (2002) Significance of vitamin D receptor gene polymorphism for risk and disease severity of prostate cancer and benign prostatic hyperplasia in Japanese. Urol Int 68: 226-231

Hutchinson PE, Osborne JE, Lear JT, Smith AG, Bowers PW, Morris PN, Jones PW, York C, Strange RC, Fryer AA (2000) Vitamin D receptor polymorphisms are associated with altered prognosis in patients with malignant melanoma. Clin Cancer Res 2: 498-504

Ikuyama T, Hamasaki T, Inatomi H, Katoh T, Muratani T, Matsumoto T (2002) Association of vitamin D receptor gene polymorphism with renal cell carcinoma in Japanese. Endocr J 49: 433 - 438

Ingles SA, Coetzee GA, Ross RK, Henderson BE, Kolonel LN, Crocitto L, Wang W, Haile RW (1998) Association of prostate cancer with vitamin D receptor haplotypes in African-Americans. Cancer Res 58: 1620-1623

Ingles SA, Garcia DG, Wang W, Nieters A, Henderson BE, Kolonel LN, Haile RW, Coetzee GA (2000) Vitamin D receptor genotype and breast cancer in Latinas (United States). Cancer Causes Control 11: 25-30

Ingles SA, Haile R, Henderson B, Kolonel L, Gerhard C (1997a) Association of vitamin $D$ receptor genetic polymorphism with breast cancer risk in African-American and Hispanic women. In Vitamin D. Chemistry, Biology and Clinical Applications of the Steroid Hormone, Norman AW, Bouillon R, Thomasset M (eds) pp 813-814, Riverside: University of California

Ingles SA, Haile RW, Henderson BE, Kolonel LN, Nakaichi G, Shi CY, Yu MC, Ross RK, Coetzee GA (1997b) Strength of linkage disequilibrium between two vitamin D receptor markers in five ethnic groups: implications for association studies. Cancer Epidemiol Biomarkers Prev 6: $93-98$

Ingles SA, Ross RK, Yu MC, Irvine RA, La Pera G, Haile RW, Coetzee GA (1997c) Association of prostate cancer risk with genetic polymorphisms in vitamin D receptor and androgen receptor. J Natl Cancer Inst 89: $166-170$

Jenkins R, Kelsall J, Bundred N, Howell A, Mawer B (1997) Vitamin D receptor polymorphisms in breast cancer patients. In Vitamin $D$. Chemistry, Biology and Clinical Applications of the Steroid Hormone, Norman AW, Bouillon R, Thomasset M (eds) pp 811-812, Riverside: University of California
Lundin AC, Soderkvist P, Eriksson B, Bergman-Jungestrom M, Wingren S (1999) Association of breast cancer progression with a vitamin D receptor gene polymorphism. South-East Sweden Breast Cancer Group. Cancer Res 59: 2332-2334

Luscombe CJ, French ME, Liu S, Saxby MF, Jones PW, Fryer AA, Strange RC (2001) Outcome in prostate cancer associations with skin type and polymorphism in pigmentation-related genes. Carcinogenesis 22: $1343-1347$

Ma J, Stampfer MJ, Gann PH, Hough HL, Giovannucci E, Kelsey KT, Hennekens CH, Hunter DJ (1998) Vitamin D receptor polymorphisms, circulating vitamin D metabolites, and risk of prostate cancer in United States physicians. Cancer Epidemiol Biomarkers Prev 7: 385-390

MacKie RM, Smyth JF, Soutar SS, Calman KC, Watson AC, Hunter JA, McLaren KM, MacGillivray JB, McPhie JL, Rankin R, Hutcheon AW, Kemp IW (1985) Malignant melanoma in Scotland 1979-1983. Lancet 2: $859-863$

Medeiros R, Morais A, Vasconcelos A, Costa S, Pinto D, Oliveira J, Lopes C (2002) The role of vitamin D receptor gene polymorphisms in the susceptibility to prostate cancer of a southern European population. J Hum Genet 47: 413-418

Merika M, Orkin SH (1993) DNA-binding specificity of GATA family transcription factors. Mol Cell Biol 13: 3999-4010

Morrison NA, Yeoman R, Kelly PJ, Eisman JA (1992) Contribution of transacting factor alleles to normal physiological variability: vitamin D receptor gene polymorphism and circulating osteocalcin. Proc Natl Acad Sci USA 89: 6665 - 6669

Osborne JE, Hutchinson PE (2001) Clinical correlates of Breslow thickness of malignant melanoma. $\mathrm{Br} J$ Dermatol 144: 476-483

Osborne JE, Hutchinson PE (2002) Vitamin D and systemic cancer: is this relevant to malignant melanoma? Br J Dermatol 147: 197-213

Rengarajan J, Szabo SJ, Glimcher LH (2000) Transcriptional regulation of Th1/Th2 polarization. Immunol Today 21: 479-483

Saijo T, Ito M, Takeda E, Huq AHMM, Naito E, Yokota I, Sone T, Pike W, Kuroda Y (1991) A unique mutation in the vitamin D receptor gene in three Japanese patients with vitamin D-dependent rickets type II: utility of single strand conformation polymorphism analysis for heterozygous carrier detection. Am J Hum Genet 49: 668-673

Schondorf T, Eisberg C, Wassmer G, Warm M, Becker M, Rein DT, Gohring UJ (2003) Association of the vitamin D receptor genotype with bone metastases in breast cancer patients. Oncology 64: 154-159

Schug J, Overton GC (1997) Modeling transcription factor binding sites with Gibbs sampling and minimum description length encoding. Proc Int Conf Intell Syst Mol Biol 5: 268-271

Sunn KL, Cock TA, Crofts LA, Eisman JA, Gardiner EM (2001) Novel N-terminal variant of human VDR. Mol Endocrinol 15: 1599-1609

Tatsumi T, Kierstead LS, Ranieri E, Gesualdo L, Schena FP, Finke JH, Bukowski RM, Mueller-Berghaus J, Kirkwood JM, Kwok WW, Storkus WJ (2002) Disease-associated bias in T helper type 1 (Th1)/Th2 CD4(+) $\mathrm{T}$ cell responses against MAGE- 6 in HLA-DRB10401(+) patients with renal cell carcinoma or melanoma. J Exp Med 196: 619-628

Taylor JA, Hirvonen A, Watson M, Pittman G, Mohler JL, Bell DA (1996) Association of prostate cancer with vitamin D receptor gene polymorphism. Cancer Res 56: 4108-4110

Watanabe M, Fukutome K, Murata M, Uemura H, Kubota Y, Kawamura J, Yatani R (1999) Significance of vitamin D receptor gene polymorphism for prostate cancer risk in Japanese. Anticancer Res 19: $4511-4514$

Whitfield GK, Remus LS, Jurutka PW, Zitzer H, Oza AK, Hope T, Dang HTL, Haussler CA, Galligan MA, Thatcher ML, Dominguez CE, Haussler MR (2000) Are human vitamin D receptor gene polymorphisms functionally significant?. In Vitamin D Endocrine System. Structural, Biological, Genetic and Clinical Aspects, Norman AW, Bouillon R, Thomasset M (eds) pp 817-823, Riverside: University of California

Wong HL, Seow A, Arakawa K, Lee HP, Yu MC, Ingles SA (2003) Vitamin D receptor start codon polymorphism and colorectal cancer risk: effect modification by dietary calcium and fat in Singapore Chinese. Carcinogenesis 24: $1091-1095$

Yamamoto H, Miyamoto K, Li B, Taketani Y, Kitano M, Inoue Y, Morita K, Pike JW, Takeda E (1999) The caudal-related homeodomain protein Cdx2 regulates vitamin $\mathrm{D}$ receptor gene expression in the small intestine. J Bone Miner Res 14: 240-247 